\title{
BRIEFING
}

\section{Is fin-tech the new panacea for poverty alleviation and local development? Contesting Suri and Jack's M-Pesa findings published in Science}

$<$ Authors:>

Milford Bateman ${ }^{\mathrm{a}, \mathrm{b}, \mathrm{c}, \mathrm{d}}$, Maren Duvendack ${ }^{\mathrm{e}}$ and Nicholas Loubere ${ }^{\mathrm{f}}$

$<$ Affiliations:>

aDepartment of Economics and Tourism, Juraj Dobrila University of Pula, Pula, Croatia; ${ }^{b}$ International Development Studies Program, St Mary's University, Halifax, Nova Scotia, Canada; 'Future Forum, Phnom Penh, Cambodia; ${ }^{\mathrm{d} I n d e p e n d e n t ~ c o n s u l t a n t ;}{ }^{\mathrm{e}}$ School of International Development, University of East Anglia, Norwich, UK; ${ }^{\mathrm{f}}$ Centre for East and South-East Asian Studies, Lund University, Lund, Sweden

CONTACT Milford Bateman_milfordbateman@yahoo.com

\begin{abstract}
SUMMARY
Financial technology, or simply 'fin-tech', is increasingly seen as one of the key tools to facilitate poverty reduction and local economic development. One article in particular by Tavneet Suri and William Jack published in the leading publication Science has played a hugely influential role in promoting the fin-tech model in the global South using the example of Kenya's iconic M-Pesa money transfer platform. The authors' central claim is that M-Pesa has been instrumental in facilitating a major episode of poverty reduction. Our analysis shows that their analysis and claims are extremely problematic.
\end{abstract}

< MAIN ARTICLE TEXT STARTS HERE $>>$

In recent years financial technology, or simply 'fin-tech', ${ }^{1}$ has come to be seen as one of the key tools to facilitate poverty reduction and local economic development (McKinsey Global Institute 2016). While there is a growing body of literature critiquing the push for digitalfinancial inclusion (see Gabor and Brooks 2017; Loubere 2017; Mader 2016), pillars of the global development establishment and global financial industry have wholeheartedly embraced the new fin-tech narrative. Leading the way are the World Bank, the G20, USAID, the Bill \& Melinda Gates Foundation, Citibank, Mastercard, and many others, all of whom are aggressively pushing for the inclusion of fin-tech in virtually all development interventions (see Häring 2017). Some commentators go so far as to say that fin-tech will have a dramatic positive impact on society, perhaps as much as the industrial revolution, suggesting its emergence as heralding a new golden age (Porteous 2017). Importantly, it is in the global South, and particularly in Kenya (see Ndung'u 2018), where the impact of fin-tech is being most rigorously tested and - it is claimed - generating the key lessons other African countries need to quickly learn in order to take advantage of its benefits. 
By far the most internationally celebrated example of fin-tech's supposed developmental potential not just in Africa, but in the global South overall, is M-Pesa - Kenya's agent-assisted, mobile phone-based, person-to-person payment and money transfer system. MPesa began as an experiment in helping smooth the flow of finance within and across Kenya's poor communities. Its origin can be traced to a project funded in the year 2000 by the United Kingdom's Department for International Development (DFID) with the aim to encourage the private sector to improve access to financial services. With an award of one million GBP to the UK multinational Vodafone, the contract was expected to deliver a product that could use mobile phone technology as a platform upon which to deliver financial services in East Africa. M-Pesa was formally launched in March 2007. It was originally expected to specialise in providing microcredit, but it was soon clear that most clients were more interested in the transfer of money, which then became the focus of M-Pesa's activity. M-Pesa operates through a network of agents that allow clients to deposit cash into their accounts and withdraw or transfer it whenever they need to. Crucially, by changing cash into 'e-balances', it is possible to send cash to another account via an SMS.

Much positive reporting since 2007 has greatly publicised and promoted the work of M-Pesa. Apart from the mere fact that, by definition, it 'includes' Kenya's poor in the local financial system, one of the most important claims relating to M-Pesa is that it possesses the power to promote economic development. For example, Beck et al. (2015) have argued that M-Pesa has helped enterprises in Kenya to scale up their operations and take advantage of economies of scale. The conclusion reached from their model (Ibid., 1) is that this enhanced access to trade credit generated as much as $0.5 \%$ of total factor productivity (TFP) growth on an annualised basis (TFP is a measure of how efficiently the basic inputs of labour and capital are used in the production process). If correct, this is no mean achievement given that, as the authors note, total factor productivity growth in Kenya was 3.3\% between 2006 and 2013.

Undoubtedly the most influential assessments of the development impact of M-Pesa to date have been authored by the US-based economists William Jack of Georgetown University and Tavneet Suri of MIT. Beginning in 2011, and based on a long-running project first funded by Financial Sector Deepening (FSD) Kenya and later by the Gates Foundation, Jack and Suri have contributed a number of important outputs that have galvanised enormous support for the M-Pesa model as a development intervention (Jack and Suri 2011; Jack and Suri 2014). However, one of their publications has resonated with the international development community above all others: a short summary article published in 2016 in one of the world's leading journals, Science. The article is entitled 'The long-run poverty and gender impacts of mobile money' and it was an attempt to measure the longer-term impact of M-Pesa using the final round of a panel survey undertaken in 2014. This article is hugely important because it introduced an astonishing claim to a large body of key stakeholders, such as practitioners, policymakers and academics: that 'access to the Kenyan mobile money system M-PESA increased per capita consumption levels and lifted 194,000 households, or 2\% of Kenyan households, out of poverty' (Suri and Jack 2016, 1288).

It is no exaggeration to say that this article and its specific poverty reduction claim have electrified the international development community. Indeed, one might say, the excitement created was probably more than for any other innovation since the microcredit movement took 
off in the 1980s (Dawson 2017). Almost every major publication from the global development institutions focusing on the fin-tech movement now opens with a reference to, or a quote from, Suri and Jack's 2016 signature article on M-Pesa (for example, United Nations 2018, 81; UNSGSA et al. 2018). Fin-tech is now seen as having a major role to play in achieving the UN's Sustainable Development Goals (SDGs) (UNCDF 2018), and Suri and Jack's article has rapidly become a cornerstone of the recent raft of uplifting articles on fin-tech (for example, see Beck and Frame 2018; Demirgüç-Kunt et al. 2018; Dupas et al. 2018). Moreover, the supposed good news about M-Pesa has also been picked up by a wide range of mainstream news media outlets, delivering the message to a broad popular audience that M-Pesa has miraculous poverty-reducing powers (Aizenman 2016; Aleem 2016; Barnett 2016).

If Suri and Jack's claims are broadly verifiable, then here we have one of the most important anti-poverty interventions of recent history. Anyone concerned with addressing global poverty, including the current authors, should be very happy indeed. However, extreme caution is warranted. This is because the recent history of the international development community is, unfortunately, littered with claims of miraculous poverty-reducing policy interventions, a great many of which are then shown at a later date to be quite ineffective and only really promoted for ideological, political, or narrow profiteering reasons. ${ }^{2}$

\section{From microcredit to fin-tech as the key to poverty reduction in the global South}

The rapid popularisation of fin-tech as a developmental solution is, in many respects, premised on the continued prominence of the quintessential local development intervention associated with the neoliberal revolution: microcredit and the broader concept of financial inclusion (Bateman 2010; Mader 2015). The microcredit movement was established and quickly validated in the 1980 s on wildly overblown and ultimately false claims that providing small loans to groups of poor women was a panacea for global poverty reduction - claims that were especially associated with its leading light and 2006 Nobel Peace Prize laureate, Dr Muhammad Yunus. ${ }^{3}$ Even though the rigorous empirical evidence supporting microcredit as an effective tool against poverty was almost entirely absent at the time (Bateman 2019), the juggernaut that was microcredit continued forward.

For microcredit to gain legitimacy within the international development community, however, empirical evidence provided by an unimpeachable source was required. This evidence came in the form of an impact evaluation undertaken in Bangladesh by then World Bank economists Mark Pitt and Shahidur Khandker (1998), which claimed that microcredit programmes had significant beneficial results for impoverished female clients. Pitt and Khandker's work quickly went on to become the most influential output on the issue as it was one of the first studies to rigorously assess microcredit impacts drawing on a quasiexperimental design alongside a sophisticated econometric strategy. It also helped that for many years Muhammad Yunus used Pitt and Khandker's findings to successfully 'sell' the microcredit model to the international development community. ${ }^{4}$ Thanks to such efforts, a general consensus emerged among a generation of academics, practitioners and international development agencies that the microcredit model was the most effective way to efficiently and quickly provide enormous benefits to the global poor. This understanding in turn catalysed into 
a massive global push to establish microcredit institutions across the global South. Even though Pitt and Khandker's impact evaluation was largely debunked many years later (Duvendack and Palmer-Jones 2012a, 2012b; Roodman and Morduch 2014), this hardly mattered because in the meantime the World Bank had achieved its goal to ensure that the microcredit model became globally ubiquitous.

By the same token, then, if Suri and Jack's results are misleading, or even false, the potential clearly exists for a major setback for the global poor, as scarce resources are committed in favour of an intervention that fails to help them, or potentially even further disadvantages them.

\section{Assessing the claims made by Suri and Jack}

Suri and Jack base their claims on a long-running household panel survey undertaken between 2008 and 2014. The key estimate of long-run impact is calculated by comparing households that experienced a large increase in access to M-Pesa agents during this time period with households that did not. Suri and Jack claim that the hugely uplifting outcome they describe is generated due to the integration of poor households into the formal financial system. In their own words: 'basic financial services such as the ability to safely store, send, and transact money - taken for granted in most advanced economies, and which in the form of mobile money have reached millions of Kenyans at unprecedented speed over the past decade - appear to have the potential to directly boost economic well-being' (Suri and Jack 2016, 1292). This formalisation of financial activity supposedly leads to changes in financial behaviour - mainly increased financial resilience and savings. Crucially, M-Pesa clients have greater opportunity to access financial resources from within their own network, which they can then use to leave unproductive subsistence agriculture and move into a range of informal microenterprise and self-employment ventures.

We have a number of problems with Suri and Jack's work, including key impact factors omitted, false logic and faulty methodology, which we think need to be identified, examined and challenged before the fin-tech narrative becomes (if it is not already) a runaway vehicle that cannot be stopped.

\section{(1) Impact of exit not discussed}

Suri and Jack claim that M-Pesa has successfully addressed poverty in Kenya by providing additional financial resources that have enabled many female clients to move out of subsistence agriculture and into microenterprises, particularly into tiny small-scale trading operations $(2016,1291)$. The movement out of subsistence agriculture and into petty trading operations generates the higher incomes and consumption found in their survey. This process amounts, they claim, to an increasingly efficient allocation of labour.

However, Suri and Jack appear not to have factored the issue of enterprise exit (failure) into their discussion or estimation of downside impact. This is surprising since in emerging economies, enterprise exit is a problem that greatly undermines all job-creation interventions, but especially microenterprise development interventions. The essential problem is that while it is relatively easy to provide financial and other stimuli to encourage certain groups to move into petty entrepreneurship, if there is no commensurate increase in local demand at the same 
time then the zero-sum end result is simply the redistribution of local demand among a larger number of market participants (see Amsden 2010). As Galbraith (1967) noted, and as is especially the case in the global South (Breman 2003; Davis 2006), the tendency for market forces and new entry is to compete away profit down to zero and wages down to subsistence levels. That this 'pure' neoclassical form of market competition exists in the world of microenterprises is why establishing a new microenterprise is difficult indeed, and most often results in failure. This accounts for why exit rates tend to be very high among newly started enterprises, which most often do not have the experience, knowledge and contacts to survive for very long, and many exit in their first year (McKenzie and Paffhausen 2017). As there are few other opportunities to find work and an income, new entry is extremely high in Africa, but so also are exit rates (Nagler and Naudé 2017; Page and Söderbom 2012).

With so many countries in the global South registering high levels of entry but also equally high levels of exit, it would appear reasonable to assume that this potentially important downside factor would have been examined by Suri and Jack. Instead, they ignore entirely the issue of exit and appear to have assumed that the increased supply of simple traded goods resulting from M-Pesa clients making the move into business will always find a market at a price that produces a positive return. If this was not the case, and instead the M-Pesa-facilitated supply of petty trade and traders predictably resulted in more aggressive competition and price falls in the local market, this would have led to the quick exit of some, if not many, of the new microenterprises established by the M-Pesa clients surveyed. This downside would naturally temper - and call into question - the positive results presented in the paper.

The failure to consider this exit issue is particularly important in the case of Kenya because we know for sure that the lack of demand in the country has led to very high levels of microenterprise exit. This was most recently highlighted in a survey undertaken by the Kenya Bureau of Statistics, which found that failure rates of microenterprises in Kenya are extremely high, with almost $46 \%$ of micro/small and medium enterprises (MSMEs) closing down less than one year after having been established (Omondi 2016).

It thus seems highly unlikely that all of the individuals surveyed by Suri and Jack established a successful microenterprise that improved their lives. Instead, as suggested above, one must surely assume that a good many of them ended up with a failed/failing business venture and that this had spiralling negative outcomes for their lives, such as through a plunge into over-indebtedness as more microloans are used in a vain attempt to keep the microenterprise functioning (see below). Even though the important consequences of exit are widely ignored in impact evaluations, as even leading World Bank economists now acknowledge, ${ }^{5}$ we find it surprising that this basic issue was not addressed, even in passing, in an article making such dramatic claims on the basis of microenterprise success, and in one of the flagship scientific publications with a notoriously stringent peer review process.

\section{(2) Impact of displacement ignored}

Going further with regard to the point above about the limits of local demand, it is also important to point out that Suri and Jack chose not to factor into their evaluation the negative displacement (or 'knock-on') effects of new entry on the wider community of the poor in Kenya. It is inevitable that the new jobs and income flows created by M-Pesa-assisted entrants 
will take local demand away from microenterprises operated by those already in the market and not using M-Pesa. Jobs and incomes in incumbent microenterprises will therefore be displaced, making the net job and income impact less than the entry statistics alone would initially suggest. This fact has led Nightingale and Coad (2014) to point out that displacement is a critical factor to account for in ultra-competitive local economies in the global South, where jobs and incomes created by new entrants are all too often cancelled out by the jobs and incomes lost in incumbent enterprises in the same neighbourhood. Indeed, high rates of displacement broadly define the situation in much of Africa (see Page and Söderbom 2012), and Kenya is very unlikely to be an exception to this rule, as pointed out by Viswanath (2018).

Suri and Jack narrowly focus on comparing the outcomes of those households that experienced a large increase in the presence of M-Pesa in the neighbourhood with those households that saw less of an increase $(2016,1288)$. There is, however, no attempt to compare the outcomes of those households managing to establish or expand a tiny retail business with the help of M-Pesa, and those households in the same community that have no engagement with M-Pesa but are already in possession of, and therefore survive because of, a tiny retail business. This is a serious omission, as a potentially significant number of the 184,000 women encouraged to move into petty trading businesses thanks to the services offered by M-Pesa will have displaced (i.e. reduced) the incomes and jobs of incumbent non-M-Pesa client microenterprises operating in the same business area in the same neighbourhood. Therefore, the net income and jobs impact of new entry stimulated by M-Pesa is likely to be quite low, if not near zero. By not attempting to estimate this downside to the operation of M-Pesa - and, in fact, not even mentioning it anywhere - Suri and Jack significantly overestimate the positive impact of M-Pesa.

Arguably, by choosing to ignore displacement altogether Suri and Jack commit the cardinal error, made by many working in the international development community (as pointed out by Amsden 2010), which is to simply assume that a form of 'Say's Law' operates in Kenya - the fallacy that 'supply creates its own demand'. This belief implicitly leads to the conclusion that the average community in Kenya is sufficiently elastic to be able to unproblematically absorb any increase in the supply of simple goods and services produced by women using MPesa to move into a new microenterprise. Unfortunately, this is highly unlikely (perhaps impossible), not least as demonstrated by previous studies on petty entrepreneurial activity induced by easier access to finance, which show severe strain being placed on communities due to sudden increases in competition ultimately reducing living standards across the board (the obvious example is post-apartheid South Africa - see Bateman 2015).

\section{(3) Rising over-indebtedness in Kenya}

Another key concern we have with Suri and Jack's work is that they choose to measure specific household increases in incomes and savings attributable to M-Pesa, but fail to calculate the impact of the wider (but gradual) increases in debt also attributable to M-Pesa. Overindebtedness has been rising to dangerous levels in almost all parts of the global South where access to microcredit has been facilitated by the international development community and others (Bateman 2010; Guérin, Labie, and Servet 2015; Guérin, Morvant-Roux, and Villarreal 2013), and thus requires serious attention in any impact evaluation. Yet, as has been 
specifically noted by many researchers to date (for example, Duvendack and Mader 2019, 14) almost no evaluations take the issue on board.

This glaring omission continues with the work of Suri and Jack. Kenya today is facing dangerously high and growing levels of over-indebtedness - a development that has arisen as a result of the operations of M-Pesa and other microcredit and fin-tech institutions (Fick and Mohammed 2018). Informally, M-Pesa makes is possible for recipients of cash transfers to end up in much higher debt to other members of their M-Pesa network (see point (5) below). More importantly, M-Pesa has made it much easier for individuals to rack up serious formal debt, such as through its partner lending application within the Safaricom group, M-Shwari. There are now more than 15 million M-Shwari accounts in a country of 50 million people, with MPesa allowing for instant loans from M-Shwari at the touch of a button. As Gordon and Lyon (2017) point out, 'If you have an M-PESA account, a phone and, in some cases, an active Facebook account, you're only a few taps away from securing an instant loan ranging from $\$ 5-\$ 500$.'

One of the most troubling ways of descending into over-indebtedness in Kenya today, as in so many other countries in the global South scarred by deep poverty and hopelessness (see Davis 2006, 183), involves gambling. It is very easy indeed to access funds via M-Pesa, including microloans, and immediately redirect them to internet gambling platforms, or else to top up accounts at regular 'bricks-and-mortar' high street gambling institutions. As of yet, very few checks and balances exist to restrain M-Pesa clients who might wish to use funds acquired via M-Pesa for gambling purposes. This has resulted in an accelerated expansion of gambling that has recently been described as an epidemic. Odundo Owuor (2018) describes 'the devastating effect betting has on many of those who participate in it [in Kenya], more than half of whom are below the age of 35', and he notes that 'low-earning young people often borrow money for betting' and are then placed 'in a cycle of perpetual debt' with no obvious way out.

Whatever its fundamental cause, the individual over-indebtedness situation in Kenya is now approaching near-crisis level. Leading financial analysts and long-time promoters of financial inclusion, such as Graham Wright (2017), express real concern that over-indebtedness is now out of control and are petitioning the Kenyan government to implement urgent measures to restrain and control the rapid growth of microcredit. ${ }^{6}$ It is, therefore, extremely difficult for us to see how the serious issue of unsustainable levels of debt - one that is very much linked to the operations of M-Pesa - can be entirely excluded from an analysis of the ongoing impact of M-Pesa.

\section{(4) Accumulation by dispossession}

Suri and Jack's analysis focuses on the benefits that M-Pesa clients supposedly gain from formalising their financial arrangements and integrating into the formal financial system: i.e. the classic argument for expanding financial inclusion. This narrow focus, however, fails entirely to capture what financial integration actually means within the wider political economy of the extractive global financial industry. Put simply, Suri and Jack do not consider issues of corporate power and legacies of imperialism, and how these might both shape markets in order to benefit powerful interests at the expense of others. 
In the 'financialised' world that emerged from the 1980s onwards, a completely new way of exploiting the financial transactions of the poor has arisen. In many respects, this can be seen as a new form of resource extractivism in the global South (see Shaxson 2018). We might call it 'digital mining'. This new extractivist model recalls previous eras of extractivism in Africa when natural resource mining and other related activities allowed colonial elites to brutally extract significant wealth from a country's many colonial possessions. This inevitably precluded local development using locally generated and recirculated wealth in favour of a model of wealth transfer out of the community to the colonial power, thereby accelerating the development of the coloniser at the expense of the colonised. Today, however, accumulating great wealth does not require the mining of physical materials but the 'mining' of the digitalfinancial transactions of the poor. The full extent of wealth generation that is possible through digital mining is only now becoming apparent in the light of several high-profile cases, one of which is M-Pesa itself.

Consider that, as of 2018, the ownership of M-Pesa resides with the Kenya-registered company, Safaricom. After numerous changes in recent years, Safaricom is today $40 \%$ owned by the UK multinational Vodafone plc, a further 35\% of Safaricom is owned by the government of Kenya, and the remaining $25 \%$ of shares are held in small tranches by a range of mainly foreign investors. Safaricom is now also Kenya's largest company by far and it alone accounts for a massive $40 \%$ of the total stock market valuation on the Nairobi securities exchange. Profits in recent years have been spectacular - in 2019 a record US\$620 million - which has allowed for equally spectacular dividends to be paid out to shareholders. ${ }^{7}$ In addition, and not surprisingly, the share price has grown sixfold in the last five years (2013-2018), thus greatly benefiting Safaricom's mainly foreign shareholders. In short, Safaricom is a huge economic asset that is generating large dividend payments and capital appreciation from its operations in Kenya, of which M-Pesa is a key component of its business model. However, this immense value has been largely repatriated back to wealthy shareholders in the UK and in other global financial centres.

With this clearly disadvantageous situation patently visible, it is strange that Suri and Jack do not make any reference to the significant amounts of digitally mined wealth being generated in, and then extracted from, Kenya because this wealth is ultimately generated by M-Pesa clients through their tiny financial transactions. When the ultimate financial proceeds of what is so far the emblematic global example of 'digital mining' are accruing not to Kenya's poor, but mainly to foreign business elites, ${ }^{8}$ the implications of this cannot be simply avoided in a development impact analysis. Instead, the entire history of Africa (Rodney 1973), and not least of Kenya itself (Wolff 1970), point to the potential for 'digital mining' to (continue to) strip poor people and countries of material wealth and development potential.

Moreover, this omission in Suri and Jack's paper occurs in spite of the fact that MPesa's facilitating role in stripping the very poorest communities of their wealth has been alarming the Kenyan government itself for some time now. Anger at the huge profits being generated from Kenya's poor finally peaked in 2018 when the Kenyan government moved to impose a $2 \%$ tax on the mobile cash transactions facilitated by M-Pesa. According to the government of Kenya, this would raise as much as US\$270 million, revenue that it planned to earmark for the universal health care programme that is supposed to cover all Kenyans by 2022 . 
Predictably, Safaricom has vigorously opposed such a tax. The company claims, without any real evidence, that any such tax will significantly reverse the gains it claims the poor have enjoyed thanks to accelerated financial inclusion, among other things by making it more expensive for Kenya's poor to transfer cash (see Kazeem 2018).

\section{(5) Wealthy versus poor networks}

Yet another problem with Suri and Jack's work relates to the logic behind the real source of the M-Pesa client gains. Suri and Jack claim that M-Pesa quickly transfers cash within the network to those most in need, rescuing vulnerable individuals and households from certain problems or else allowing them to quickly take advantage of a specific business opportunity. It is well known from the critical literature on social capital that, by definition, having extensive links to wealthy individuals and institution enables a poor individual to parlay such links into a material gain (Fine 2001). In essence, having richer friends and relatives means one has a better chance of escaping poverty, which is hardly a novel concept. Unfortunately, this obvious reality is ignored in the paper's hypothesis. Rather, Suri and Jack $(2016,1291)$ make no definitive claim as to the cause of the rise in consumption, pointing out that 'The higher consumption levels we observed could be driven by increased labor or capital income, or simply by transfers between individuals with different propensities to consume' (our italics). In other words, the increase in consumption they observe could simply result from wealth being passed along fin-tech-enabled linkages to others in the same family or social circle or class. This is hardly a ground-breaking finding, but simply underlines the value of links to wealthy individuals.

All of this points to the fact that M-Pesa will resolve poverty only to the extent that those in your family and/or social group are wealthy enough and willing to provide financial support. The extent of pre-existing wealth in one's network is, therefore, the crucial factor to discuss here, and surely far more important than the question of how quickly one can obtain access to such funds. Suri and Jack all too conveniently forget the importance of established extended family wealth to people's success in life, especially in places with high levels of inequality like Africa, and instead narrowly focus on how wealth can be transferred within a family group as if ease of access was the key limiting factor. One might also argue that, to the extent that it assists already wealthy family networks to assist their less successful members, M-Pesa is not so much helping the poor to escape their poverty but assisting the already wealthy to deploy their wealth in order to help only their narrow family circle. This will inevitably feed into rising inequality.

Suri and Jack do not consider the rather important fact that not all networks and social circles are created equal. Those with an extended network of wealthy family and friends connected to M-Pesa will find it much easier to access finance when in trouble, or presented with a business opportunity to exploit. On the other hand, those individuals without wealthy extended family and friends are not so fortunate. If you have wealthy connections that are willing to quickly send money, M-Pesa can assist an individual. However, if you are in a network with few wealthy individuals, then no matter how quickly you can potentially access any funds, there might not actually be anything to access. 
Moreover, some researchers accept the importance of social networks but go on to argue that extending financial support to one's network with the help of M-Pesa is ultimately destructive. For example, Kusimba, Kunyu, and Gross (2018) acknowledge that M-Pesa helps to mediate cash among a social group where some contribute to, and some take out of, the common pool. But they go further and point to the fact that this inevitably results in a social debt that needs repaying later - possibly double - when cash is put into the pool, and that this social debt is ultimately damaging to the social network in question. Suri and Jack thus fail to take into account the extent to which rising debt and reciprocity is so often corrosive of social networks, and ultimately destroys them if programmatically used by some as a way out of individual poverty. This is an inexcusable omission considering the existence of a substantial body of literature examining the ways in which microcredit programmes - particularly those utilising joint liability loan groups - serve to undermine local social and familial groups through the introduction of formal debt relations, as well as to reinforce unequal and exploitative power relations at the local level (see for instance, Bee 2011; Guérin, Kumar, and Agier 2013; Loubere 2018; Maclean 2010; Rankin 2002).

\section{(6) Flawed impact evaluation methodology}

Attempting to measure long-term effects through a household panel survey is commendable. However, it is a serious omission for Suri and Jack not to construct a counterfactual scenario: that is, there is no control group that would simulate what would have happened in the absence of the intervention. Because of this we cannot conclude that the impacts Suri and Jack claim to observe can be attributed to the intervention itself (i.e. to M-Pesa) rather than to something else that may have occurred at the same time, such as changes in the overall economic environment.

Related to this problem is the wider fact that, by the standards of impact evaluations today, the analytical approach adopted by Suri and Jack lacks sophistication. A regression analysis may be a valid approach to control for possible selection bias due to observable characteristics that distinguish participants and non-participants, but Suri and Jack only follow participants over time without knowing much about how they have selected themselves, or have been selected by others, into the intervention. Moreover, the sample size appears to be small given the high levels of attrition, which Suri and Jack acknowledge to be 'nontrivial' (2016, 1288). Reporting of power calculations would have been useful (and this is standard practice in the impact evaluation arena nowadays) to judge what the appropriate sample size should have been. Ultimately, these methodological oversights, and lack of methodological sophistication, are surprising in a paper published in Science.

Suri and Jack also make the central claim that it is the easier access to M-Pesa agents in the community that underpins the ability to constructively engage with the informal sector, thereby causing wealth creation. However, this direction of causation is debatable. This is because M-Pesa agents, just as with other financial units seeking profit elsewhere in Africa, ${ }^{9}$ are well known for proliferating in wealthier urban areas where there are more opportunities to obtain large client numbers and wealthier clients, the combination of which is more likely to generate higher financial returns. This logical business decision of M-Pesa agents to seek out and move into wealthier and more populated urban areas might thus explain the supposed link found by Suri and Jack between the proliferation of M-Pesa agents and the economic success 
of M-Pesa clients. In other words, it is not access to M-Pesa agents that explains (causes) wealth creation but the presence of wealthier clients that explains (causes) the higher density of MPesa agents.

\section{Conclusion}

Our view on the rise of fin-tech as the new 'development darling' is that all that glitters is not gold, and our reading of Suri and Jack's signature article in Science is that it does not stand up to scrutiny. In fact, Suri and Jack's work contains so many serious errors, omissions, logical inconsistencies and flawed methodologies that it is actually correct to say that they have helped to catalyse into existence a largely false narrative surrounding the power of the fin-tech industry to advance the cause of poverty reduction and sustainable development in Africa (and elsewhere). Going further, one simply cannot overlook the coincidence that Suri and Jack's flawed work has been sponsored and widely promoted by two important institutions - FSD Kenya and the Gates Foundation - that are not neutral observers with regard to the fin-tech movement, but are perhaps the most important advocates for it in Africa. The obvious possibility arises, therefore, that Suri and Jack's work was always less about genuinely exploring the real impact of M-Pesa, good or bad, and more a work that has used weak logic and a flawed impact methodology in order to skew the results in such a way as to obtain the positive impact results required by their sponsors. Was the whole purpose of Suri and Jack's work simply to provide a headline-grabbing claim that could then be utilised by the international development community to justify its promotion of the fin-tech movement? Referring to the previous issue of a flawed evaluation by Pitt and Khandker that was aggressively used by the World Bank and others (especially Muhammad Yunus) to 'sell' the microcredit model to the world, we might therefore ask: are Suri and Jack the new Pitt and Khandker?

It has been widely documented that self-censorship of impact results in order to produce findings that are comforting to elite donors is pervasive in much of the US academic economics and impact evaluation communities (see Duvendack and MacLean 2015; Häring and Douglas 2012). There is also the furore surrounding the positive results obtained by Pitt and Khandker, mentioned previously, which turned out not to describe the real situation in Bangladesh (for a more realistic view of the situation there, see Karim 2011; Maîtrot 2019; Paprocki 2016) any more than their conclusions as to the power of microcredit per se represented the general global situation (Bateman, Blankenburg, and Kozul-Wright 2019). The global poor will therefore not be well served by allowing yet another hyped-up intervention to succeed in gaining popularity and validation on the basis of one extremely problematic impact evaluation. For this reason, we have determined that it is necessary to forcefully push back against the claims made in the study by Suri and Jack, and to contest the dominant narrative depicting fin-tech as the new panacea for poverty reduction and local development.

There is little doubt that fin-tech has the potential to liberate enormous value. The digital finance sector has been expanding at a mind-boggling rate from China to Southeast Asia, from Africa to Latin America. But the core problem as it stands - as illustrated in Kenya and other places around the world - is that the bulk of this value does not go to the poor. Rather, fin-tech is very clearly designed to hoover up value and deposit it into the hands of a narrow 
global digital-financial elite that are the main forces behind the fin-tech revolution. Of course, this enormous wealth could be redirected towards Kenya's poor population and reinvested locally, for example through community-owned financial institutions and financial cooperatives, but there would appear to be little time, sympathy, or political support for building such pro-poor institutions when so much wealth can be appropriated by so few so quickly in another way. The 2008 global financial crisis showed the world that an exciting new innovation said to be of huge benefit to America's poor minority communities - sub-prime mortgages - was actually expressly designed to enrich a narrow Wall Street financial elite. And when the bubble burst, it was the poor who disproportionately suffered the consequences. Worryingly, in the rise of fin-tech as a development strategy, we see many of the same precursors to previous financial collapses that have wreaked havoc on local communities and the livelihoods of their poor inhabitants. Suri and Jack's headline-grabbing study in one of the world's most prestigious scientific publications has served to generate huge levels of enthusiasm for fin-tech 'solutions' to poverty. This is simply because their flawed study failed to depict M-Pesa and fin-tech more generally for what it really is - a financial 'innovation' that enriches elites at the expense of the poor, while also shifting risks to the poor themselves, ultimately ensuring that it is the poor that will be the ones most devastated by a future financial collapse.

\section{Notes}

\section{Disclosure statement}

No potential conflict of interest was reported by the author.

\section{Notes on contributors}

Milford Bateman is a Visiting Professor of Economics in the Department of Economics and Tourism, Juraj Dobrila University at Pula, Croatia, an Adjunct Professor in Development Studies at St Mary's University, Halifax, Canada and an Affiliated Researcher at the Future Forum in Phnom Penh, Cambodia. He is the author of Why doesn't microfinance work? The destructive rise of local neoliberalism, published by Zed Books in 2010, with a second updated edition due for publication in 2020.

Maren Duvendack is a Senior Lecturer (Associate Professor) in Development Economics at the School of International Development, University of East Anglia, Norwich, United Kingdom. Her key research areas cover applied micro-econometrics, impact evaluation, systematic reviews and meta-analysis, microfinance, replication and reproduction of quantitative analyses as well as research ethics. Her main teaching is on the MSc Impact Evaluation for International Development.

Nicholas Loubere is an Associate Senior Lecturer in the Study of Modern China at the Centre for East and South-East Asian Studies, Lund University. He is the author of Development on loan: microcredit and marginalisation in rural China, forthcoming in 2019 with Amsterdam University Press.

\section{References}

Aizenman, Nurith. 2016. "Dial M For Money: Can Mobile Banking Lift People Out Of Poverty?" NPR (US National Public Radio), December 9. 
https://www.npr.org/sections/goatsandsoda/2016/12/09/504540392/dial-m-for-money-can-mobilebanking-lift-people-out-of-poverty.

Aleem, Zeeshan. 2016. "Cellphones Have Lifted Hundreds of Thousands of Kenyans Out of Poverty." Vox, December 8. https://www.vox.com/world/2016/12/8/13875908/kenya-mobile-money-mpesapoverty.

Amsden, A. 2010. "Say's Law, Poverty Persistence, and Employment Neglect." Journal of Human Development and Capabilities 1 (1): 57-66.

Barnett, David. 2017. "M-Pesa Mobile Phones are Transforming the Lives of East Africans." The Independent, February 20. http://www.independent.co.uk/news/m-pesa-mobile-phones-aretransforming-the-lives-of-east-africans-a 7590341.html.

Bateman, M. 2010. Why Doesn't Microfinance Work? The Destructive Rise of Local Neoliberalism. London: Zed Books.

Bateman, M. 2015. "South Africa's Post-apartheid Microcredit Experiment: Moving from Stateenforced to Market-enforced Exploitation." Forum for Social Economics 48 (1).

doi:10.1080/07360932.2015.1056202.

Bateman, Milford. 2019. 'Impacts of the Microcredit Model: Does Theory Reflect Actual Practice?' In The Rise and Fall of Global Microcredit: Development, Debt and Disillusion, edited by Milford Bateman, Stephanie Blankenburg, and Richard Kozul-Wright, 42-68. London and New York: Routledge.

Bateman, M., S. Blankenburg, and R. Kozul-Wright (eds). 2018. The Rise and Fall of Global Microcredit: Development, Debt and Disillusion. Oxford: Routledge.

Beck, Thorsten, and W. Scott Frame. 2018. "Technological Change, Financial Innovation, and Economic Development." In Handbook of Finance and Development, edited by Thorsten Beck and Ross Levine, 369-390. Cheltenham: Edward Elgar.

Beck, Thorsten, Haki Pamuk, Ravindra Ramrattan, and Burak R. Uras. 2015. "Mobile Money, Trade Credit and Economic Development: Theory and Evidence.” Discussion Paper No. 2015-023. Tilburg, Netherlands: Tilburg University.

Bee, Beth. 2011. "Gender, Solidarity and the Paradox of Microfinance: Reflections from Bolivia." Gender, Place \& Culture 18 (1): 23-43.

Breman, Jan. 2003. The Labouring Poor: Patterns of Exploitation, Subordination and Exclusion. Oxford: Oxford University Press.

Chang, Ha-Joon, and Ilene Grabel. 2004. Reclaiming Development: An Alternative Economic Policy Manual. London: Zed Books.

Davis, M. 2006. Planet of Slums. London: Verso.

Dawson, Stella. 2017. "Why Does M-PESA Lift Kenyans Out of Poverty?" CGAP (Consultative Group to Assist the Poor) Blog, January 18. https://www.cgap.org/blog/why-does-m-pesa-liftkenyans-out-poverty.

Demirgüç-Kunt, A., L. Klapper, D. Singer, and P. Van Oudheusden. 2015. “The Global Findex Database 2014: Measuring Financial Inclusion around the World." Policy Research Working Paper 73255, Washington, DC: World Bank. 
Dupas, Pascaline, Dean Karlan, Jonathan Robinson, and Diego Ubfal. 2018. "Banking the Unbanked? Evidence from Three Countries." American Economic Journal: Applied Economics 10 (2): 257-297.

Duvendack, Maren, and Kate Maclean. 2015. "(Mis)Use of Evidence in Microfinance Programming in the Global South: A Critique.” Contemporary Social Science 201 (15): 202-211.

Duvendack, Maren, and Philip Mader. 2019. "Impact of Financial Inclusion in Low- and Middleincome Countries: A Systematic Review of Reviews." Campbell Systematic Reviews 2019:2. doi: 10.4073/csr.2019.2.

Duvendack, Maren, and Richard Palmer-Jones. 2012a. "High Noon for Microfinance Impact Evaluations: Re-investigating the Evidence from Bangladesh." Journal of Development Studies 48(12): $1864-1880$.

Duvendack, Maren, and Richard Palmer-Jones. 2012b. "Response to Chemin and to Pitt." Journal of Development Studies 48 (12): 1892-1897.

Fick, Maggie, and Omar Mohammed. 2018. "Kenya Moves to Regulate Fintech-fuelled Lending Craze.” Reuters, May 25. https://www.reuters.com/article/us-kenya-fintech-insight/kenya-moves-toregulate-fintech-fuelled-lending-craze-idUSKCN1IQ1IP.

Fine, Ben. 2001. Social Capital Versus Social Theory. London and New York: Routledge.

Gabor, Daniela, and Sally Heather Brooks. 2017. "The Digital Revolution in Financial Inclusion: International Development in the Fintech Era." New Political Economy 22 (4): 423-436.

Galbraith, John Kenneth. 1967 [1978]. The New Industrial State. 3rd Edition. Boston: Houghton Mifflin.

Gordon, Bennett, and Ben Lyon. 2017. "4 Trends Driving a Looming Credit Crisis in East Africa." Medium, August 14. https://medium.com/dfs-lab/4-trends-driving-a-looming-credit-crisis-in-eastafrica-844b217369fd.

Guérin, Isabelle, Santhosh Kumar, and Isabelle Agier. 2013. "Women's Empowerment: Power to Act or Power over Other Women? Lessons from Indian Microfinance." Oxford Development Studies 41 (1): 76-94.

Guérin, I., M. Labie, and J-M. Servet, eds. 2015. The Crises of Microcredit. London: Zed Books. Guérin, Isabel, S. Morvant-Roux, and M. Villarreal, eds. 2013. Microfinance, Debt and Overindebtedness: Juggling with Money. London: Routledge.

Häring, Norbert. 2017. "Modi, Yunus and the Financial Inclusion Mafia." Money and More, March 26. http://norberthaering.de/en/31-english/802-modi-yunus.

Häring, Norbert, and Niall Douglas. 2012. Economists and the Powerful: Convenient Theories, Distorted Facts, Ample Rewards. London: Anthem Press.

Hulme, David. 2008. "The Story of the Grameen Bank: From Subsidised Microcredit to Market-based Microfinance." BWPI Working Paper 60. Manchester: Brooks World Poverty Institute, University of Manchester. http://hummedia.manchester.ac.uk/institutes/gdi/publications/workingpapers/bwpi/bwpiwp-6008.pdf.

Jack, William, and Tavneet Suri. 2011. "Mobile Money: The Economics of M-PESA.” NBER Working Paper No. 16721. Cambridge, MA: National Bureau of Economic Research. https://www.nber.org/papers/w16721. 
Jack, William, and Tavneet Suri. 2014. "Risk Sharing and Transactions Costs: Evidence from Kenya’s Mobile Money Revolution.” American Economic Review 104 (1): 183-223.

Karim, L. 2011. Microfinance and its Discontents: Women in Debt in Bangladesh. Minneapolis: University of Minnesota Press.

Kazeem, Yomi. 2018. "M-Pesa is Pushing Against a Tax Hike on Mobile Money services in Kenya." Quartz, June 19. https://qz.com/africa/1309097/m-pesa-opposing-kenya-mobile-money-tax-increase/.

Khandker, Shahidur R. 2005. "Microfinance and Poverty: Evidence Using Panel Data from Bangladesh." The World Bank Economic Review 19 (2): 263-286.

Kusimba, Sibel, Gabriel Kunyu, and Elizabeth Gross. 2018. "Social Networks of Mobile Money in Kenya." In Money at the Margins: Global Perspectives on Technology, Financial Inclusion, and Design, edited by Bill Maurer, Smoki Musaraj, and Ivan Small, 179-199. New York and London: Berghahn.

Loubere, Nicholas. 2017. "China’s Internet Finance Boom and Tyrannies of Inclusion.” China Perspectives 2017 (4): 9-18.

Loubere, Nicholas. 2018. "Indebted to Development: Microcredit as (De)Marginalisation in Rural China." Journal of Peasant Studies 45 (3): 585-609.

Maclean, Kate. 2010. “Capitalizing on Women's Social Capital? Women-targeted Microfinance in Bolivia." Development and Change 41 (3): 495-515.

Mader, P. 2015. The Political Economy of Microfinance: Financialising Poverty. London: Palgrave Macmillan.

Mader, Philip. 2016. "Card Crusaders, Cash Infidels and the Holy Grails of Digital Financial Inclusion.” Behemoth - A Journal on Civilisation 9 (2): 59-81.

Maîtrot, M. 2019. "Sustainability Paradigm to Paradox: A Study of Microfinance Clients' Livelihoods in Bangladesh." In The Rise and Fall of Global Microcredit: Development, Debt and Disillusion, edited by M. Bateman, S. Blankenburg, and R. Kozul-Wright, 143-165. Oxford: Routledge.

McKenzie, David, and Anna Luisa Paffhausen. 2017. "Small Firm Death in Developing Countries." Policy Research Working Paper No. 8236. Washington, DC: World Bank.

McKinsey Global Institute. 2016. Digital Finance for All: Powering Inclusive Growth in Emerging Economies. McKinsey \& Company.

https://www.mckinsey.com/ /media/McKinsey/Featured\%20Insights/Employment\%20and\%20Growt h/How $\% 20$ digital $\% 20$ finance $\% 20$ could $\% 20$ boost $\% 20$ growth $\% 20 \mathrm{in} \% 20$ emerging $\% 20$ economies $/ \mathrm{MG}$ I-Digital-Finance-For-All-Executive-summary-September-2016.ashx.

Muhatia, Abel. 2019. "What Safaricom's Sh63.4bn Profit Can Do for Economy.” The Star, May 4. Accessed from https://www.the-star.co.ke/business/2019-05-04-what-safaricoms-sh634bn-profit-cando-for-economy/.

Nagler, Paula, and Wim Naudé. 2017. "Non-farm Entrepreneurship in Rural Sub-Saharan Africa: New Empirical Evidence.” Food Policy 67: 175-191.

Ndung'u, Njuguna. 2018 Next Steps in The Digital Revolution in Africa: Inclusive Growth and Job Creation Lessons from Kenya. Africa Growth Initiative. Washington, DC: Brookings Institution.

Nightingale, P., and A. Coad. 2014. "Muppets and Gazelles: Political and Methodological Biases in Entrepreneurship Research." Industrial and Corporate Change 23 (1): 113-143. 
Odundo Owuor, Victor. 2018. "There's a Troubling Relationship Between the Rise in Online Betting and Mobile Money's Growth." Quartz Africa, April 25. https://qz.com/africa/1261369/theres-atroubling-relationship-between-the-rise-in-online-betting-and-mobile-moneys-growth/.

Omondi, Dominic. 2016. "Why 400,000 SMEs are Dying Annually." Standard Media, October 29. https://www.standardmedia.co.ke/business/article/2000221491/why-400-000-smes-are-dyingannually.

Page, J., and M. Söderbom. 2012. "Small is Beautiful? Small Enterprise, Aid and Employment in Africa." UNU WIDER Working Paper no. 2012/94, November. Helsinki: WIDER.

Paprocki, K. 2016. “'Selling Our Own Skin': Social Dispossession through Microcredit in Rural Bangladesh." Geoforum 74: 29-38.

Pitt, Mark, and Shahidur Khandker. 1998. "The Impact of Group-based Credit Programs on Poor Households in Bangladesh: Does the Gender of Participants Matter?" Journal of Political Economy 106 (5): 958-996.

Porteous, David. 2017. “The 'Golden Age' of Digital Finance in China.” Digital Frontiers Institute, February 9. https://digitalfrontiersinstitute.org/switch/component/easyblog/entry/2017/02/the-goldenage-of-digital-finance-in-china?Itemid=thought-leadership.

Rankin, Katharine N. 2002. "Social Capital, Microfinance, and the Politics of Development." Feminist Economics 8 (1): 1-24.

Rice, Xan. 2007. "Kenyan Inquiry into Vodafone's Mystery Partner." The Guardian, February 16. https://www.theguardian.com/media/2007/feb/16/kenya.citynews.

Rodney, Walter. 1973. How Europe Underdeveloped Africa. London and Dar es-Salaam: BogleL'Ouverture Publications and Tanzanian Publishing House.

Roodman, David, and Jonathan Morduch. 2014. "The Impact of Microcredit on the Poor in Bangladesh: Revisiting the Evidence.” Journal of Development Studies 50 (4): 583-604.

Shaxson, Nicholas. 2018. The Finance Curse: How Global Finance Is Making Us All Poorer. London: Vintage.

Suri, Tavneet, and William Jack. 2016. "The Long-run Poverty and Gender Impacts of Mobile Money.” Science 354 (6317): 1288-1292.

UNCDF (United Nations Capital Development Fund). 2018. UNCDF and the SDGs: Financial Inclusion and the SDGs. http://www.uncdf.org/financial-inclusion-and-the-sdgs.

United Nations. 2018. Financing for Development: Progress and Prospects 2018 -Report of the Inter-Agency Task Force on Financing for Development. New York: United Nations.

UNSGSA (United Nations Secretary-General's Special Advocate for Inclusive Finance for Development), Better than Cash Alliance, UNCDF (United Nations Capital Development Fund), and World Bank. 2018. Igniting SDG Progress Through Digital Financial Inclusion. Washington, DC: United Nations.

Viswanath, P. V. 2018. "Microcredit and Survival Microenterprises: The Role of Market Structure." International Journal of Financial Studies 6 (1). https://doi.org/10.3390/ijfs6010001.

Weisbrot, Mark. 2015. Failed: What the "Experts" Got Wrong About the Global Economy. Oxford and New York: Oxford University Press. 
Wolff, Richard D. 1970. "Economic Aspects of British Colonialism in Kenya, 1895 to 1930." The Journal of Economic History 30 (1): 273-277.

Wright, Graham. 2017. "Digital Credit - Have We Not Been Here Before With Microfinance?"

Microsave Blog, August 21. http://blog.microsave.net/digital-credit-have-we-not-been-here-beforewith-microfinance/.

1 Fin-tech is defined as: 'Computer programs and other technology used to support or enable banking and financial services'. See https://en.oxforddictionaries.com/definition/fintech.

2 One obvious example would be structural adjustment programmes (SAPs), which were all the rage in the 1980s and 1990s, but are now widely seen as misguided and as having undermined development and poverty reduction in the global South (Chang and Grabel 2004; Wiesbrot 2015). Another would be in agriculture. Many economists in the post-war world, especially in the foodexporting USA, thought that substantial food aid was unequivocally a good thing for the global South. This policy was later shown to be a decided negative because it undermined the construction of successful domestic agricultural sectors, which was found to be a critical factor in promoting development and growth from the bottom up, especially through the building of backward and forward linkages between and within sectors.

3 Leading international development economist David Hulme $(2008,6)$ has written that, '[Yunus] energetically promoted microenterprise credit as a panacea for poverty reduction (something that intensely annoyed me, as it was so wrong).'

4 Based on the data produced by Pitt and Khandker, Yunus skilfully deployed a 'killer quote' to the effect that 'some 5 per cent of borrowers may lift themselves out of poverty each year by borrowing from a microfinance program' (see Khandker 2005, 266). For many in the international development community, this was a momentous claim that simply could not be resisted.

5 World Bank economists David McKenzie and Anna Luisa Paffhausen $(2017,2)$ argue that a form of 'intentional ignorance' exists when evaluating the impact of microenterprise development interventions, because the issue of exit is simply ignored. Pointedly, they see this bias even in work by those celebrating and utilising the supposedly more accurate randomised controlled trial (RCT) methodology, noting the biased results produced by the fact that "Almost two-thirds of published randomized experiments testing policy interventions for small firms in developing countries ignore firm death completely, neither reporting the death rate nor examining it as an outcome.'

6 See 'An Open Letter to Central Bank of Kenya Governor Patrick Njoroge', LinkedIn, August 6, 2018. Accessed at https://www.linkedin.com/pulse/open-letter-central-bank-kenya-governor-patricknjoroge-graham-wright.

7 Safaricom's full year results ending 31 March 2019 showed that it generated KSh250 billion revenue (of which M-Pesa accounts for just over 31\%) and made a net profit of KSh63.4 billion (around US\$620 million). This represents a nearly 15\% increase on 2018's profit of KSh55.4 billion and the seventh straight year of rising profits. The profit of the year to end March 2019 was mainly paid out as dividends, with the total dividend payout rising from KSh44.07 billion in 2018 to KSh50.08 billion in 2019 (KSh1.25 per share). In addition, Safaricom's board of directors agreed to pay out in 2019 an additional 'special dividend' to shareholders of KSh24.84 billion (KSh0.62 per share) in order to reflect the record-breaking year (Muhatia 2019). 
8 However, a small share of these vast gains has been corruptly channelled to Kenya's elites through an off-shore tax haven shell company, Mobitelea Ventures, which for a long time was one of the minority shareholders in Safaricom. Thanks to a very complicated ownership structure, going through Guernsey and then on into various offshore tax havens in the Caribbean, the final beneficiaries of Mobitelea Ventures have never been formally identified. Vodafone plc has always pointedly refused to identify the real owners of Mobitelea, claiming 'commercial confidentiality'. However, most analysis concludes that members of the Kenyan ruling elite stood behind the company, using it as a vehicle with which to pressure Vodafone plc into allowing them to privately take advantage of Safaricom's economic potential. This goal was achieved when Mobitelea's ownership stake in Safaricom was later sold back to Vodafone in two tranches, in 2003 and in 2009, making very significant profits for those hidden Mobitelea investors (Rice 2007).

9 In neighbouring South Africa, for instance, the leading microcredit agencies have crowded into the mining areas precisely because large volumes of expensive microcredit could be more easily sold to comparatively higher-earning (but often financially illiterate) miners: it was the not the presence of more microcredit agencies in the mining areas that created the higher incomes (Bateman 2015). 